\title{
Potentials of the Circulating Pruritogenic Mediator Lysophosphatidic Acid in Development of Allergic Skin Inflammation in Mice
}

\section{Role of Blood Cell-Associated Lysophospholipase D Activity of Autotaxin}

Yoshibumi Shimizu, ${ }^{*}$ Yoshiyuki Morikawa, ${ }^{\dagger}$ Shinichi Okudaira, ${ }^{\ddagger}$ Shigenobu Kimoto, ${ }^{\dagger}$ Tamotsu Tanaka, ${ }^{*}$ Junken Aoki, and Akira Tokumura*

From the Department of Pharmaceutical Health Chemistry, * the Institute of Health Biosciences, University of Tokushima Graduate School, Tokushima; the Technical Service Department, ${ }^{\dagger}$ Clea Japan, Tokyo; and the Department of Molecular and Cellular Biochemistry, ${ }^{\ddagger}$ the Graduate School of Pharmaceutical Sciences, Tohoku University, Sendai, Japan

\author{
Accepted for publication \\ January 16, 2014. \\ Address correspondence to \\ Akira Tokumura, Ph.D., \\ Department of Pharmaceutical \\ Health Chemistry, Institute of \\ Health Biosciences, University \\ of Tokushima Graduate School, \\ 1-78-1 Shomachi, Tokushima \\ 770-8505, Japan. E-mail: \\ tokumura@tokushima-u.ac.jp.
}

\begin{abstract}
Itching and infiltration of immune cells are important hallmarks of atopic dermatitis (AD). Although various studies have focused on peripheral mediator-mediated mechanisms, systemic mediatormediated mechanisms are also important in the pathogenesis and development of AD. Herein, we found that intradermal injection of lysophosphatidic acid (LPA), a bioactive phospholipid, induces scratching responses by Institute of Cancer Research mice through LPA $_{1}$ receptor- and opioid $\mu$ receptor-mediating mechanisms, indicating its potential as a pruritogen. The circulating level of LPA in Naruto Research Institute Otsuka Atrichia mice, a systemic AD model, with severe scratching was found to be higher than that of control BALB/C mice, probably because of the increased lysophospholipase $D$ activity of autotaxin (ATX) in the blood (mainly membrane associated) rather than in plasma (soluble). Heparan sulfate proteoglycan was shown to be involved in the association of ATX with blood cells. The sequestration of ATX protein on the blood cells by heparan sulfate proteoglycan may accelerate the transport of LPA to the local apical surface of vascular endothelium with LPA receptors, promoting the hyperpermeability of venules and the pathological uptake of immune cells, aggravating lesion progression and itching in Naruto Research Institute Otsuka Atrichia mice. (Am J Pathol 2014, 184: 1593-1603; http://dx.doi.org/10.1016/j.ajpath.2014.01.029)
\end{abstract}

Atopic dermatitis (AD) is a chronically relapsing skin disorder with pruritic and eczematous skin lesions. In animal models of $\mathrm{AD}$ and a large population of patients with $\mathrm{AD}$, specific leukocytes, including eosinophils and lymphocytes, become increasingly recruited from the blood into lesional skin areas, leading to release of peripheral mediators involved in pruritus. ${ }^{1,2}$ The pathogenesis and development of $\mathrm{AD}$ are thought to be regulated by complex arrays of genes and environmental factors. Among the animal models of $\mathrm{AD}$, NC/Nga mice commonly develop an eczematous AD-like skin lesion around the face under conventional conditions because of mite allergens. ${ }^{3}$ Unlike the NC/Nga mouse, the Naruto Research Institute Otsuka Atrichia (NOA) mouse, a hair-deficient mutant, develops ulcerative skin lesions in a specific pathogen-free environment. ${ }^{4}$ In NOA mice, atopic lesions expand to cover a wide area of the animal's skin and are exacerbated by aging. These mouse models display ADlike symptoms, including itching, elevated serum IgE level,

Supported in part by the Ministry of Education, Culture, Sports, Science, and Technology of Japan grants-in-aid for scientific research (A.T.).

Disclosures: None declared. 
increased numbers of mast cells, eosinophils, and lymphocytes in the dermis, and a type 2 helper T-cell-biased immune response. These lines of evidence suggest that the animals are a useful model for both examining mechanisms of the pathogenesis and aggression and acquiring a fundamental basis for novel treatments of AD.

Lysophosphatidic acid (LPA) is a physiologically important phospholipid mediator acting on a wide range of animal cells, including several inflammatory cells through $\mathrm{G}$ proteincoupled LPA receptors. ${ }^{5,6}$ LPA was shown to induce chemokinesis of Jurkat $\mathrm{T}$ cells ${ }^{7}$ and to promote invasion and polarization of mouse lymphoma lines via binding to and activation of LPA receptors. ${ }^{8}$ In addition, LPA was shown to enhance infiltration of guinea pig and mouse eosinophils into bronchoalveolar lavage fluid in vivo, ${ }^{9,10}$ and to induce migration and oxygen radical production of human eosinophils in vitro ${ }^{11}$ Its circulating level is tightly controlled by a balance of LPA-producing with LPA-degrading enzyme activities in mammals. ${ }^{12,13}$ In mice, the production of LPA in the blood is assumed to be largely due to the lysophospholipase D (lysoPLD) activity of autotaxin (ATX) because the plasma LPA level of heterozygous mice $\left(A T X^{+/-}\right)$is approximately half that of wild-type (WT) mice. ${ }^{14}$ Recently, Lundequist and Boyce ${ }^{15}$ demonstrated that $\mathrm{LPA}_{5}$ is abundantly expressed by human mast cells and partially involved in LPA-induced calcium mobilization and macrophage inflammatory protein- $1 \beta$ release. In addition, LPA was shown to induce plasma exudation and proliferation of human mast cells. ${ }^{16,17}$ The evidence allowed us to hypothesize that an increased concentration of circulating LPA is involved in the pathological accumulation of inflammatory cells to the skin lesion sites and contributes to the development of systemic AD.

\section{Materials and Methods}

\section{Reagents}

Heparinase III from Flavobacterium heparinum, EDTA-2K, and fatty acid-free bovine serum albumin (BSA) were from Sigma-Aldrich (St. Louis, MO). Heparin was from Wako Pure Chemicals Industries (Osaka, Japan). Dioctanoylglycerol pyrophosphate (8:0 DGPP), 1-pentadecanoyl-lysophosphatidylcholine (15:0-LPC), 1-palmitoyl-LPC (16:0), 1heptadecanoyl-LPC (17:0), and sphingosine 1-phosphate (S1P; d17:1) were from Avanti Polar Lipids (Alabaster, AL). 1-Linoleoyl-LPC (18:2) was prepared from 1,2-dilinoleoyl-PC (Avanti Polar Lipids) with porcine pancreas phospholipase $\mathrm{A}_{2}$ (Sigma-Aldrich), as described previously. ${ }^{18}$ 1-PentadecanoylLPA, 1-heptadecanoyl-LPA, and 1-linoleoyl-LPA were prepared from 1-pentadecanoyl-LPC, 1-heptadecanoyl-LPC, and 1-linoleoyl-LPC, respectively, with Streptomyces chromofuscus phospholipase D (PLD; Sigma-Aldrich), as described previously. ${ }^{19}$ 1-Oleoyl-18:1-lysophosphatidylmethanol (LPM) was prepared from 1-oleoyl-LPC (Avanti Polar Lipids) by transphosphatidylation with Actinomadura sp. PLD (Seikagaku Biobusiness, Tokyo, Japan). ${ }^{20}$ In brief, 18:1-LPC (15 mg) was dissolved in $2 \mathrm{~mL}$ of diethyl ether, $0.5 \mathrm{~mL}$ of $10 \%$ methanol, and $0.2 \mathrm{~mL}$ of $0.22 \mathrm{~mol} / \mathrm{L} \mathrm{CaCl}_{2}$. The reaction was started by adding $20 \mathrm{U}$ of PLD dissolved in $0.4 \mathrm{~mL}$ of $0.2 \mathrm{~mol} / \mathrm{L}$ sodium acetate. The reaction mixture was stirred vigorously for 3 hours at $65^{\circ} \mathrm{C}$. The product, 18:1-LPM, was separated on a silica gel thin-layer plate with a mixture of chloroform/methanol $/ \mathrm{H}_{2} \mathrm{O}(65: 35: 5, \mathrm{v} / \mathrm{v} / \mathrm{v})$, and extracted from the corresponding zone. 1-Linolenoyl-LPA (18:3) was prepared from 1,2-dilinolenoyl-PC (Avanti Polar Lipids) with phospholipase $\mathrm{A}_{2}$ and PLD reactions, as previously described. S32826 was from Calbiochem (San Diego, CA) and Cayman Chemical (Ann Arbor, MI). HA130 was from Calbiochem. Ki16425 was from Cayman Chemical. Histamine dihydrochloride and naloxone hydrochloride were from Alexis-Enzo Life Sciences (Farmingdale, NY).

\section{Animals}

The NOA mouse, a hair-deficient mutant, was established as an inbred strain in 1997 by Kondo. ${ }^{4}$ The NC/Nga mice were established as an inbred strain by Kondo et $\mathrm{al}^{21}$ on the basis of Japanese fancy mice. Male BALB/c and NOA mice obtained from Clea Japan (Tokyo) were housed under specific pathogenfree conditions. Male NC/Nga mice were obtained from Japan SLC (Shizuoka) and housed under conventional conditions. Female Institute of Cancer Research (ICR) mice were obtained from Japan SLC and housed under specific pathogen-free conditions. Mice were given free access to a standard chow (DC-8; Clea Japan) and water. Mice were handled in accordance with the Guidelines for Animal Experimentation of the Tokushima University School of Medicine (Tokushima, Japan), and all animal experiments were approved by the Tokushima University Animal Experiment Committee.

\section{Sampling and Hematological Analysis}

Mouse blood was collected from the vena cava or eye socket after 12 hours of fasting. Mouse blood anticoagulated with $1 \mathrm{mg} /$ $\mathrm{mL}$ EDTA-2K or $3 \mathrm{U} / \mathrm{mL}$ heparin was centrifuged at $1200 \times g$ for 25 minutes at $4{ }^{\circ} \mathrm{C}$ to obtain the plasma and hemocyte fraction. Mouse platelet-rich plasma (PRP) was prepared by centrifugation of blood at $50 \times g$ for 20 minutes at $20^{\circ} \mathrm{C}$. Hematological variables, such as the white blood cell (WBC) count, red blood cell count, hemoglobin concentration $(\mathrm{g} / \mathrm{dL})$, hematocrit percentage, mean cell volume (fL), mean cell hemoglobin (pg), mean cell hemoglobin concentration $(\mathrm{g} / \mathrm{dL})$, and platelet count, were recorded by an automated hematological analyzer (Celltac- $\alpha$ MEK-6358; Nihon Kohden, Tokyo). Subpopulation analysis of WBCs was performed using the mouse-specified profile on a veterinary hematological analyzer (Sysmex XT-2000iV; Sysmex Corp, Kobe, Japan).

\section{LC-MS/MS of LPC, LPA, and S1P}

LPC, LPA, and S1P were extracted from EDTA-treated mouse plasma using a modified Bligh and Dyer method. In brief, 0.1 
$\mathrm{mL}$ of the plasma was vortex mixed with a mixture of chloroform-methanol-water $(1: 2: 0.6, \mathrm{v} / \mathrm{v} / \mathrm{v} ; 1.8 \mathrm{~mL})$ for 1 minute. Specific amounts of internal standards (17:0-LPA, 17:0-LPC, and C17-S1P) were added to the mixture. The mixtures were separated into two phases by addition of $0.5 \mathrm{~mL}$ each of chloroform and water containing $20 \mathrm{mg} \mathrm{KCl}$. After adjusting the $\mathrm{pH}$ of the aqueous phase to 2 to 3 with $5 \mathrm{~N} \mathrm{HCl}$, the chloroform-rich lower layer was separated and dried under a stream of $\mathrm{N}_{2}$ gas. Extracted lipids were reconstituted with a small volume of solvent used as a mobile phase for reversephase liquid chromatography (LC) and analyzed by an LC-tandem mass spectrometry (MS/MS) system with 4000QTRAP (AB SCIEX, Foster City, CA) equipped with an Agilent 1100 high-performance LC pump (Agilent Technologies, Waldbronn, Germany) and an HTS-PAL autosampler (CTC Analytics, Zwingen, Switzerland). LPCs in the lipid extract were separated on an Ascentis Express C18 column (2.7 $\mu \mathrm{m}$, $2.1 \times 150 \mathrm{~mm}$; Supelco, Bellefonte, PA) developed with an isocratic solvent system of methanol-water mixture $(19: 1, \mathrm{v} / \mathrm{v})$ containing $5 \mathrm{mmol} / \mathrm{L}$ ammonium formate at $0.2 \mathrm{~mL} /$ minute. Acidic polar phospholipids, such as LPA and S1P, in the lipid extract were separated on an ODS-100Z column $(5 \mu \mathrm{m}, 2.0$ $\times 150 \mathrm{~mm}$; Tosoh, Tokyo) developed with an isocratic solvent system of methanol-water mixture $(19: 1, \mathrm{v} / \mathrm{v})$ containing 5 $\mathrm{mmol} / \mathrm{L}$ ammonium formate at $0.2 \mathrm{~mL} /$ minute. For quantification, LPC was analyzed by positive-ion electrospray ionization (ESI) with multiple reaction monitoring of parent $\left[(\mathrm{M}+\mathrm{H})^{+}\right] /$daughter $\left[(\text {phosphocholine })^{+}\right]$at $\mathrm{m} / \mathrm{z} 184$, where $\mathrm{M}$ is the molecular weight of the parent species. LPAs were quantified in $\mathrm{ESI}^{-}$with multiple reaction monitoring of parent $\left[(\mathrm{M}-\mathrm{H})^{-}\right] /$daughter ions [(cyclic glycerophosphate $\left.)^{-}\right]$at $\mathrm{m} / \mathrm{z}$ 153. S1P was analyzed in $\mathrm{ESI}^{-}$mode using a combination of deprotonated molecular ions and a fragmented ion at $\mathrm{m} / \mathrm{z}, 79$ $\left(\mathrm{PO}_{3}^{-}\right)$. Quantification was accomplished by referencing peak areas to those of the internal standards. Analytical conditions for MS/MS were described previously. ${ }^{22}$

\section{Assay of LPL Activity toward LPA}

Plasma from $0.1 \mathrm{~mL}$ heparin-anticoagulated blood samples was added to a tube in which 15:0-LPA from an aliquot of stock solution had been dried. The final concentration of 15:0-LPA was $0.002 \mathrm{mmol} / \mathrm{L}$. The plasma sample was gently vortex mixed and incubated for 12 or 24 hours at $37^{\circ} \mathrm{C}$. After incubation, 200 pmol 17:0-LPA was added to the incubation mixture as an internal standard, and lipids, including unmetabolized 15:0-LPA, were extracted by the method of Bligh and Dyer after acidification of the aqueous phase to $\mathrm{pH} 2$ to 3. 15:0-LPA in the lipid extract was quantified in reference to the internal standard (17:0-LPA) by LC-MS/MS, as previously described.

\section{Assay of LPP Activity toward LPA}

Heparin-anticoagulated blood samples $(0.1 \mathrm{~mL})$ were added to the tube with 15:0- or 18:3-LPA at a final concentration of $0.06 \mathrm{mmol} / \mathrm{L}$. The samples were gently vortex mixed and incubated for 1 or 10 minutes at $37^{\circ} \mathrm{C}$. After incubation, 6000 pmol 17:0-LPA was added to each sample as an internal standard. Unmetabolized 15:0- or 18:3-LPA was extracted from the incubated mixture by the method of Bligh and Dyer after acidification of the aqueous phase $(\mathrm{pH}$ 2 to 3), and followed by LC-MS/MS of unmetabolized LPA, as previously described.

\section{Assay of LysoPLD Activity}

LysoPLD activity was assayed essentially as described previously. ${ }^{23}$ First, $0.04 \mathrm{~mL}$ heparin-anticoagulated venous blood or plasma sample was diluted with $0.098 \mathrm{~mL}$ saline. Second, $0.06 \mathrm{~mL}$ of $16: 0$ - or 18:2-LPC solution $(0.167$ or $0.5 \mathrm{mmol} / \mathrm{L}$ ), dispersed in saline buffer containing $0.25 \%$ fatty acid-free BSA, was added to the diluted blood or plasma sample. The final concentrations of LPC were 0.05 or $0.15 \mathrm{mmol} / \mathrm{L}$. Third, $0.002 \mathrm{~mL}$ of dimethyl sulfoxide (DMSO) solution of an ATX inhibitor (S32826 or HA130) or vehicle alone was added to the mixture. The final concentration of DMSO was $1 \%$. The mixture was incubated for various times at $37^{\circ} \mathrm{C}$. After incubation, it was centrifuged at $8250 \times g$ for 1 minute at $4^{\circ} \mathrm{C}$, and $0.2 \mathrm{~mL}$ of 7.5 $\mathrm{mmol} / \mathrm{L}$ 3-(4-hydroxyphenyl)propionic acid, $2.6 \mathrm{~mL} 0.1$ $\mathrm{mol} / \mathrm{L}$ Tris- $\mathrm{HCl}(\mathrm{pH} 8.5)$, and $0.1 \mathrm{~mL} 2 \mathrm{U} / \mathrm{mL}$ horseradish peroxidase were added to $0.1-\mathrm{mL}$ aliquots of the reaction mixture. After the addition of $0.01 \mathrm{~mL}$ of $300 \mathrm{U} / \mathrm{mL}$ choline oxidase solution, $\lambda_{\text {ex }}$ fluorescence was determined at 320 $\mathrm{nm}$ and $\lambda_{\text {em }}$ at $404 \mathrm{~nm}$.

\section{Western Blot Analysis}

For determination of ATX antigen levels, $0.03 \mathrm{~mL}$ of 10 fold diluted plasma, blood, or hemocyte fraction samples was mixed with $0.01 \mathrm{~mL}$ of sample-loading buffer $(250$ $\mathrm{mmol} / \mathrm{L}$ Tris-HCl, $\mathrm{pH}$ 6.8, 8\% SDS, 5\% 2-mercaptoethanol, $40 \%$ glycerol, and a trace amount of bromophenol blue), heated at $90^{\circ} \mathrm{C}$ for 5 minutes, and separated by $10 \%$ SDSPAGE. Separated proteins in the gels were electrophoretically transferred onto polyvinylidene difluoride membranes (ATTO, Tokyo) at $108 \mathrm{~mA}$ for 90 minutes. After blocking the membranes with 5\% skim milk in Tris-buffered saline containing $0.05 \%$ Tween 20 , membranes were incubated with an antibody raised against human ATX (3D1, 150-fold diluted) overnight at room temperature, as described previously. ${ }^{24}$ After washing with Tris-buffered saline containing $0.05 \%$ Tween 20 , the membrane was incubated with horseradish peroxidase-conjugated goat anti-rat IgG (American Qualex, San Clemente, CA; diluted 2000-fold) for 2 hours. After washing, the immunoreactive bands were detected by enhanced chemiluminescence Prime Western blot detection reagent (GE Healthcare Life Sciences, Piscataway, NJ) with an LAS-4000 mini image analyzer (Fujifilm, Tokyo). The intensity of the band was quantified with use of the software Multi Gauge, version 3.2 (Fujifilm). 
A

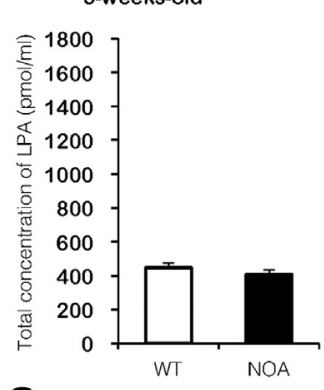

C

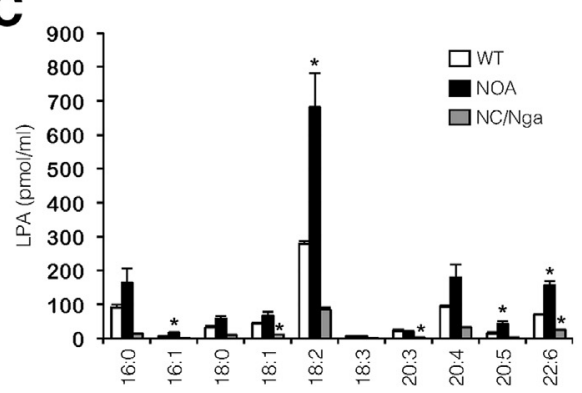

B

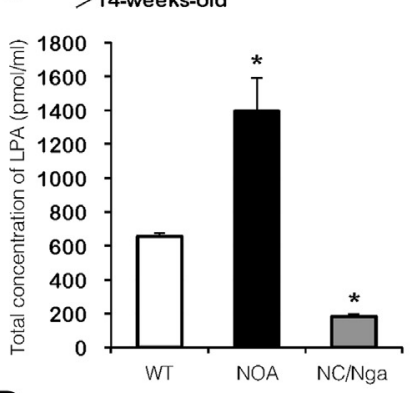

D

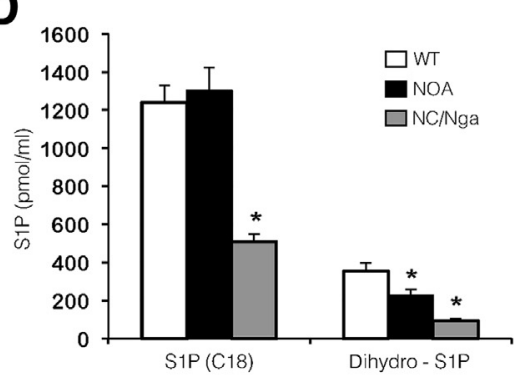

Figure 1 Plasma levels of LPAs, S1P, and dihydro-S1P in mice. A: Total plasma levels of LPA in 5-week-old WT $(n=9)$ and NOA $(n=9)$ mice. B: Total plasma levels of LPA in aged ( $>14$-weekold) WT $(n=3)$, NOA $(n=6)$, and NC/Nga $(n=8)$ mice. C: Plasma levels of individual LPAs in aged (>14-week-old) WT $(n=3)$, NOA $(n=6)$, and NC/Nga $(n=8)$ mice. D: Plasma levels of S1P and dihydro-S1P in aged (>14-weekold) WT $(n=3)$, NOA $(n=6)$, and NC/Nga $(n=8)$ mice. Data are means \pm SE. ${ }^{*} P<0.05$ versus age-matched WT mice.
Measurement of Itch

The scratching behavior with 5- to 6-week-old female ICR mice was observed according to the method described. ${ }^{25-27}$ The hair was clipped over the rostral part of the back 1 day before intradermal injection of the pruritogen. On the test day, mice were individually placed in a $12 \times 20 \times 16-\mathrm{cm}$ observation cage to acclimate them for approximately 60 minutes. After acclimation, 50, 100, or $150 \mathrm{nmol}$ per site histamine, $150 \mathrm{nmol}$ per site 18:2-LPA, or $150 \mathrm{nmol}$ per site 18:1-LPM was injected intradermally, without anesthesia, in a volume of $0.05 \mathrm{~mL}$ of saline containing $0.25 \%$ fatty acid-free BSA. Mice were held in a mouse holder (KN-330; Natsume Seisakusho Co, Ltd, Tokyo) during injection to prevent struggling. Immediately after injection, the mice were put back into the observation cage and videotaped with no one present. Usually, mice scratch with their paws several times a second; therefore, a series of these scratches was counted as one scratch event. Naloxone hydrochloride $(1 \mathrm{mg} / \mathrm{kg})$ was s.c. administered near the injection site 10 to 12 minutes before pruritogen addition, in a volume of $0.05 \mathrm{~mL} .{ }^{28}$ DGPP $(1 \mathrm{mg} / \mathrm{kg})$ and Ki16425 $(1 \mathrm{mg} / \mathrm{kg})$ were co-administered with the pruritogen. DGPP and naloxone hydrochloride were dissolved in saline containing $0.25 \%$ fatty acid-free BSA. Ki16425 was dissolved in ethanol and diluted with saline containing $0.25 \%$ fatty acid-free BSA.

\section{Statistics}

Statistical evaluation of the data was performed by one-way analyses of variance for independent or correlated samples, followed by Tukey's test or Student's $t$-test for paired and correlated samples. $P<0.05$ was considered statistically significant.

\section{Results}

\section{Quantification of LPA and S1P in Plasma}

To examine the involvement of circulating LPA in the pathogenesis of AD-like skin lesions, we measured the plasma level of LPA in young mice (aged 5 weeks, no lesions) and old mice (aged $>14$ weeks, 3 to 5 months, severe lesions). Although no significant difference in the plasma levels of LPA was observed in 5-week-old WT controls (BALB/c) and NOA mice (Figure 1A), NOA mice developed an age-dependent increase in the plasma level of LPA versus WT mice (1394 \pm 195 versus $656 \pm 19.6 \mathrm{pmol} /$ $\mathrm{mL} ; P<0.05)$, and $>14$-week-old NC/Nga mice have a lower plasma level of LPA than age-matched WT mice (Figure 1B). Molecular species analysis by LC-MS/MS showed that the plasma levels of 16:1-, 18:2-, 20:5-, and 22:6-LPAs were significantly higher in NOA mice (aged $>14$ weeks) than in WT mice (aged $>14$ weeks). However, there were no significant differences in the levels of other LPA species (Figure 1C). We also analyzed the plasma levels of S1P, another important member of the lysophospholipid mediator family, and its dihydro-form, sphinganine 1-phosphate. The plasma level of dihydro$\mathrm{S} 1 \mathrm{P}$ in NOA mice (aged $>14$ weeks) was lower than that of WT mice (aged $>14$ weeks). However, there were no differences in the plasma level of S1P (Figure 1D). Interestingly, plasma levels of S1P and dihydro-S1P in NC/Nga mice were lower than those in NOA and WT mice (Figure 1D).

\section{Activity of LPA-Degrading Enzyme}

Because the plasma level of LPA was significantly higher in NOA mice than in WT mice, we speculated that activities of 

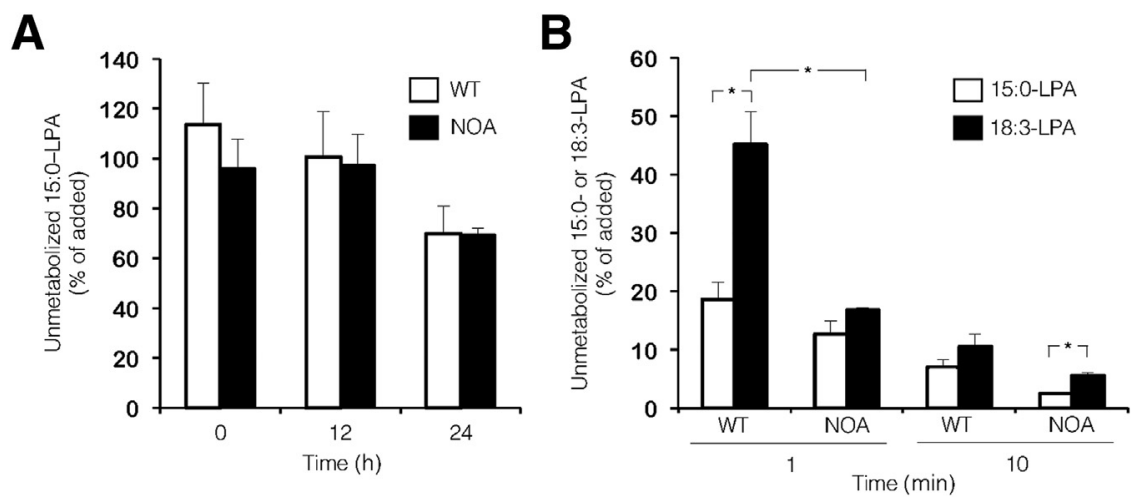

Figure 2 LPA-degrading enzyme activities in mouse blood and plasma. A: LPL activity was determined by measuring unmetabolized 15:0-LPA after incubation. Mouse plasma was incubated with $2 \mu \mathrm{mol} / \mathrm{L} 15: 0-\mathrm{LPA}$ at $37^{\circ} \mathrm{C}$ for 12 or 24 hours. B: LPP activity was determined by measuring unmetabolized 15:0- or 18:3-LPA after incubation. Mouse blood was incubated with 15:0- or 18:3-LPA (final, $0.06 \mathrm{mmol} / \mathrm{L}$ ) at $37^{\circ} \mathrm{C}$ for 1 or 10 minutes. Data are means \pm SE of triplicate determinations. ${ }^{*} P<0.05$.

LPA-degrading enzymes [soluble lysophospholipase A (LPL) and membrane-bound lipid phosphate phosphatase (LPP)] in the blood circulation of NOA mice were lower than those of WT mice. We estimated blood cell-associated and soluble LPA-degrading activities by measuring the degradation rate of exogenous 15:0-LPA (or 18:3-LPA) after its incubation with diluted whole blood or plasma. As shown in Figure 2A, there was no difference between the soluble LPL activities toward 15:0-LPA in NOA and WT mice. Unexpectedly, LPP activity in the whole blood of NOA mice was significantly higher than that of WT mice (Figure 2B). Interestingly, LPP activity toward 18:3-LPA was significantly lower than that toward 15:0-LPA at some time points, as shown in Figure $2 \mathrm{~B}$, indicating the substrate preference of the LPP in mouse blood for saturated LPAs over unsaturated LPAs.

\section{LysoPLD Activity of Soluble ATX}

Because our results indicated that the higher plasma LPA level in aged NOA mice compared with that of aged WT mice was not due to increased LPA-degrading activity, we next measured the LPA-producing activity. LPA in the circulating blood of mice is produced from lysophospholipids, such as LPC, by lysoPLD activity of ATX. ${ }^{29}$ First, we measured the plasma level of LPC, a physiological precursor of LPA, by LC-MS/MS. Although no significant difference in the plasma levels of LPC was observed in WT and NOA mice at 5 weeks of age (Figure 3A), NOA mice developed an age-dependent decrease in the plasma level of LPC versus WT mice $(273 \pm 22.8$ versus $449 \pm 23.4$ $\mathrm{nmol} / \mathrm{mL} ; P<0.05$ ) (Figure 3B). Second, molecular species analysis showed that the plasma levels of 16:0-, 18:1-, 18:2-, 20:3-, 20:4-, and 22:6-LPCs in NOA mice (aged $>14$ weeks) were significantly lower than those of WT mice (aged $>14$ weeks) (Figure 3C). Similar results were obtained for $\mathrm{NC} / \mathrm{Nga}$ mice (Figure 3, B and C). Consistent with these results, activities of lysoPLD toward endogenous LPCs in the diluted plasma in NOA and NC/Nga mice were significantly lower than those of WT mice (Figure 3D). However, no significant differences were found in the lysoPLD activities toward exogenous 0.15 mmol/L 16:0-LPC between NOA and WT mice and 18:2LPC among NOA, NC/Nga, and WT mice (Figure 3D).
A

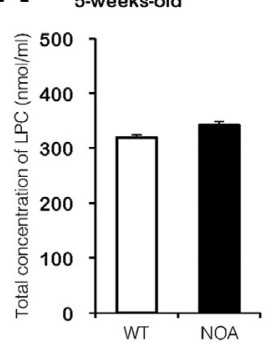

C

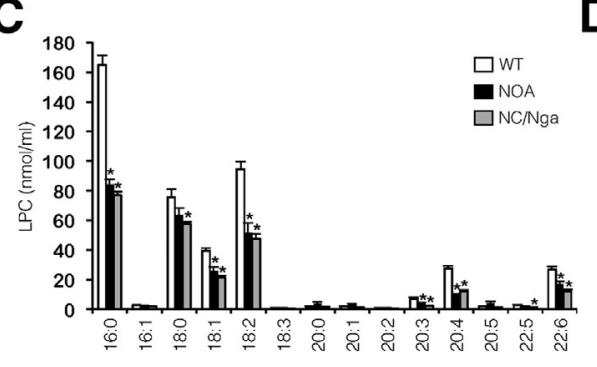

B

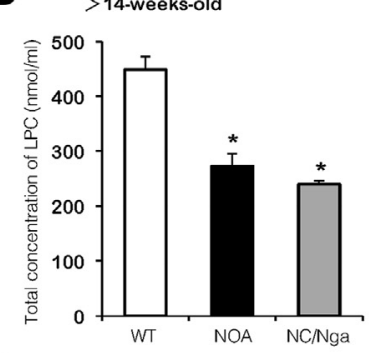

D

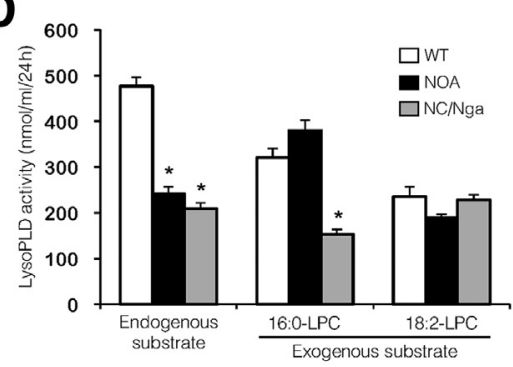

Figure 3 LC-MS/MS of LPC and lysoPLD activity measurement of mouse plasma. A: Total plasma levels of LPC in 5-week-old WT $(n=9)$ and NOA $(n=9)$ mice. B: Total plasma levels of LPC in aged (>14-week-old) WT $(n=3)$, NOA $(n=6)$, and $\mathrm{NC} / \mathrm{Nga}(n=8)$ mice. C: Plasma levels of molecular species of LPC in aged ( $>14$-week-old) WT $(n=3), \mathrm{NOA}(n=6)$, and NC/Nga $(n=8)$ mice, as measured by LC-MS/MS. D: LysoPLD activity in plasma of aged (>14-week-old) WT $(n=6)$, NOA $(n=5)$, and NC/Nga $(n=8)$ mice was measured as choline-releasing activity of soluble ATX on incubation of diluted plasma, with or without exogenous LPC. Data are means \pm SE. ${ }^{*} P<0.05$ versus age-matched WT mice. 


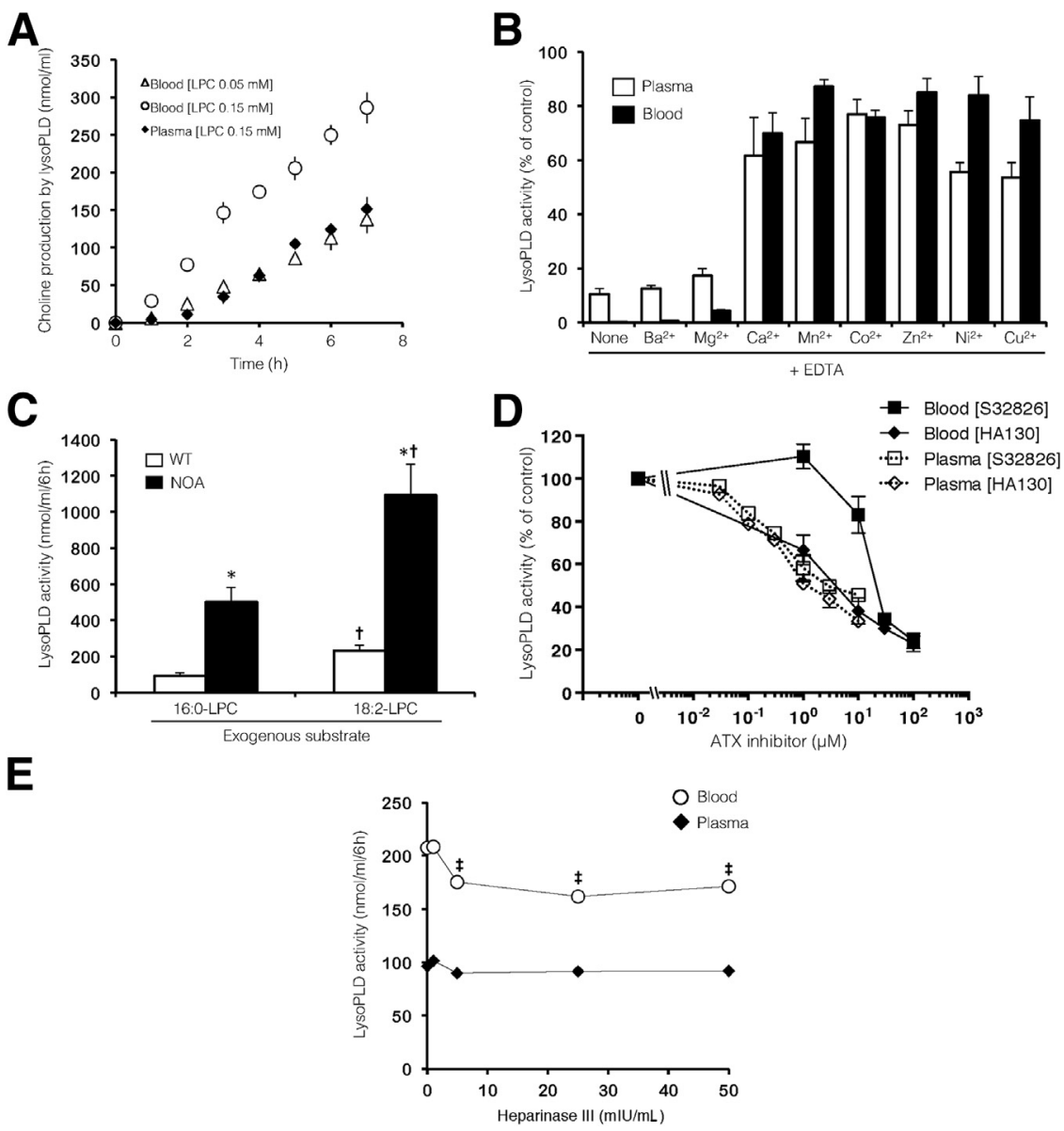

Figure 4 Characterization of blood cellassociated lysoPLD activity due to ATX. A: Time courses of choline release due to the lysoPLD activities of blood and plasma from WT mice were measured at the indicated times during incubation with $0.05 \mathrm{mmol} / \mathrm{L}$ 18:2-LPC (triangles) or 0.15 $\mathrm{mmol} / \mathrm{L} \mathrm{18:2-LPC} \mathrm{(circles} \mathrm{and} \mathrm{closed} \mathrm{diamonds).}$ B: Effect of co-addition of an equimolar amount of divalent cation with EDTA (final, $0.75 \mathrm{mmol} / \mathrm{L}$ ) on lysoPLD activity of diluted plasma or blood from WT mice toward $0.15 \mathrm{mmol} / \mathrm{L} \mathrm{18:2-LPC}$ for 6 hours. Values are relative to those without EDTA and divalent cation, set as $100 \%$. C: LysoPLD activities of blood from WT and NOA mice were measured after incubating diluted blood with $0.15 \mathrm{mmol} / \mathrm{L} 16: 0$ - or 18:2-LPC for 6 hours at $37^{\circ} \mathrm{C}$. D: LysoPLD activities of plasma (white symbols) or blood (black symbols) samples from WT mice were measured after incubation with $0.15 \mathrm{mmol} / \mathrm{L} 18: 2-\mathrm{LPC}$ in the presence of various concentrations of $\mathbf{S} 32826$ (squares) or HA130 (diamonds) for 6 hours at $37^{\circ} \mathrm{C}$. Values are relative to those with vehicle (DMSO) alone, set as $100 \%$. E: LysoPLD activities of plasma or blood samples from WT mice were measured after incubation with $0.15 \mathrm{mmol} / \mathrm{L} 18: 2-$ LPC in the presence of indicated concentrations of heparinase III (final concentration of the assay mixture) for 6 hours at $37^{\circ} \mathrm{C}$. Plasma or blood samples were predigested with various concentrations of heparinase III in saline for 15 minutes at $37^{\circ} \mathrm{C}$ before assay for lysoPLD activity. Data are means \pm SD of triplicate determinations. ${ }^{*} P<0.05$ versus $W T ;{ }^{\dagger} P<0.05$ versus $16: 0$-LPC; ${ }^{\ddagger} P<0.05$ versus $0 \mathrm{mIU} / \mathrm{mL}$ heparinase III.

\section{LysoPLD Activity of Membrane-Bound ATX}

Although the plasma LPA level was greatly increased in aged NOA mice with severe lesions compared with aged WT mice, reduced and unaltered soluble lysoPLD activity of ATX was observed toward endogenous and exogenous LPCs, respectively, in NOA mice compared with WT mice. Recently, ATX was shown to bind to cells via cell-surface molecules, including integrins ${ }^{30,31}$ and heparan sulfate proteoglycans (HSPGs). ${ }^{32}$ To determine whether ATX also acts as a membrane-bound form in the mouse blood circulation, we first measured the time dependency of lysoPLD activity with the whole blood of a WT mouse. The lysoPLD activity toward exogenous $0.15 \mathrm{mmol} / \mathrm{L} 18: 2$-LPC in the blood was higher than those in plasma and blood incubated with 0.15 and $0.05 \mathrm{mmol} / \mathrm{L}$ 18:2-LPC, respectively (Figure 4A). Consistent with human plasma and fetal calf serum lysoPLD activity, ${ }^{29,33}$ addition of a divalent cation chelator, such as EDTA, to the diluted blood almost completely inhibited the blood lysoPLD activity (Figure 4B). Co-addition of $\mathrm{Ca}^{2+}, \mathrm{Mn}^{2+}, \mathrm{Co}^{2+}, \mathrm{Zn}^{2+}, \mathrm{Ni}^{2+}$, or $\mathrm{Cu}^{2+}$ with EDTA to diluted plasma or blood at equimolar concentrations masked the inhibitory effect of EDTA, whereas $\mathrm{Ba}^{2+}$ and $\mathrm{Mg}^{2+}$ failed to do so (Figure 4B). The blood lysoPLD activity in NOA mice toward 16:0- or 18:2-LPC for 6 hours was significantly higher than that in WT mice (Figure 4C). In addition, the blood lysoPLD activity toward 18:2-LPC was significantly higher than that toward 16:0-LPC in both NOA and WT mice (Figure 4C). LysoPLD activity in the plasma from WT was inhibited in a dose-dependent manner by the addition of the ATX-selective inhibitor HA130 or S32826 (Figure 4D). Although the lysoPLD activities in the blood plasma were inhibited in a dose-dependent manner by the ATX inhibitor, S32826, a much higher concentration of this ATX inhibitor was required for inhibition of lysoPLD activity in the blood (Figure 4D). To test the possibility that S32826 was degraded by the blood cells, we compared the amounts of S32826 remaining in the plasma and blood after incubation. After $0.03 \mathrm{mmol} / \mathrm{L} \mathrm{S32826}$ was incubated with plasma or $0.3 \mathrm{mmol} / \mathrm{L} \mathrm{S} 32826$ was incubated with blood of WT mice for 6 hours, unmetabolized S32826 was revealed by LC-MS/MS to be $92.6 \% \pm 12.9 \%$ and $39.2 \% \pm 6.2 \%$, respectively, of that added. To test the involvement of HSPGs in mediating the binding of blood cells to ATX, we first treated the blood of WT mice with heparinase III to remove surface HSPGs, and then tested the lysoPLD activity of these blood samples. As shown in Figure 4E, the heparinase treatment resulted in a significant decrease in the lysoPLD activity of the blood, but had no effect on the plasma from WT mice. 
Table 1 Blood Cell Composition and LysoPLD Activity of Mouse PRP

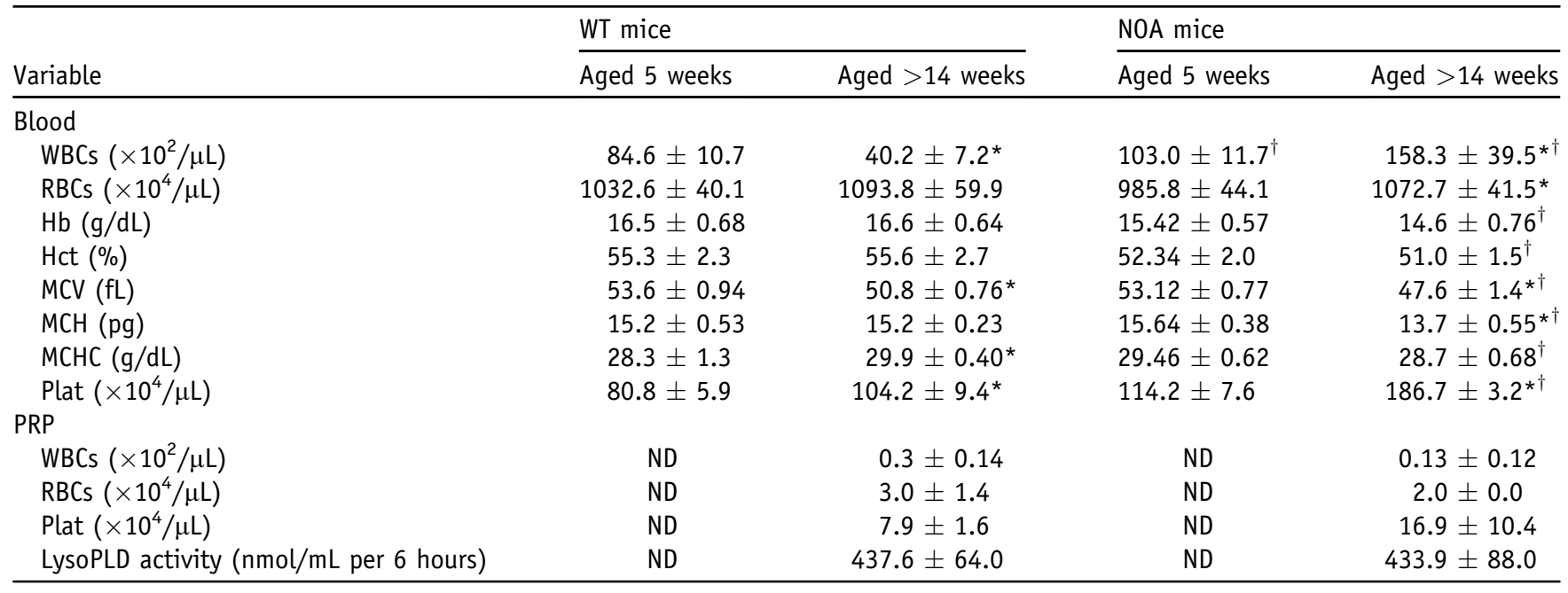

Cells in blood and PRP were counted using Celltac- $\alpha$ MEK-6358 (Nihon Kohden) and Sysmex XT-2000iV (Sysmex Corp) cell counters, respectively. LysoPLD activity in the PRP sample was assessed after incubation with $0.15 \mathrm{mmol} / \mathrm{L}$ 18:2-LPC dispersed in BSA-saline buffer for 6 hours at $37^{\circ} \mathrm{C}$. Data are means \pm SE of at least three separate experiments.

${ }^{*} P<0.05$ versus strain-matched $5 \mathrm{w}$ mice.

${ }^{\dagger} P<0.05$ versus age-matched WT mice.

$\mathrm{Hb}$, hemoglobin; Hct, hematocrit; $\mathrm{MCH}$, mean cell hemoglobin; $\mathrm{MCHC}$, MCH concentration; MCV, mean cell volume; ND, not determined; Plat, platelet; RBC, red blood cell.

Next, we compared the blood cell compositions of NOA and WT mice to investigate which blood cell type is responsible for the binding with ATX. The number of circulating WBCs was $22 \%$ higher in NOA mice than in WT mice at 5 weeks of age (Table 1). Because AD-like skin lesions developed in NOA mice with aging, the number of circulating WBCs of NOA mice (aged $>14$ weeks) increased to fourfold that of the age-matched WT mice (Table 1). In addition, the numbers of circulating platelets were $41 \%$ and $79 \%$ higher, respectively, in NOA (aged 5 and $>14$ weeks) mice than those in the WT mice (Table 1). Next, we attempted to compare the lysoPLD activities in PRP from WT and NOA mice at the age of $>14$ weeks. Although the number of platelets in PRP was $114 \%$ higher in NOA than in WT mice, no differences were observed in the lysoPLD activity of PRP between NOA and WT mice (Table 1). Thus, we speculated that WBCs are a more likely target for ATX binding in the blood circulation of the mouse, and compared the subpopulations of WBCs between WT and NOA mice at the age of $>14$ weeks. Consistent with the results of Table 1, the number of circulating WBCs was higher in NOA than in WT mice (Figure 5A). The proportion of lymphocytes was significantly higher in NOA than in WT mice (Figure 5A). To determine whether the protein level of ATX is increased in NOA mice, we separated proteins from the plasma, blood, and hemocyte fractions by SDS-PAGE and analyzed them by immunoblot with the ATX antibody (Figure 5B). Densities of ATX bands were much higher in the blood and hemocyte fraction of NOA mice than those of WT mice (Figure 5B), consistent with the higher blood lysoPLD activity of NOA mice.

\section{LPA-Mediated Pruritus}

Figure 6 illustrates the magnitude of scratching responses induced by several pruritic agents in female ICR mice. Histamine injected intradermally induced a pruritic response in a dose-dependent manner (Figure 6A). The intradermal injection of LPA produced significant scratching behavior at a dose of 150 nmol per site; however, the number of LPAinduced scratches was lower than that induced by histamine. Combined application of $150 \mathrm{nmol} \mathrm{LPA}$ and $50 \mathrm{nmol}$ histamine increased scratching behavior additively (Figure 6). The LPM at a dose of $150 \mathrm{nmol}$ per site also induced a pruritic response (Figure 6B). This observation is consistent with previous research showing that LPM is a pan-LPA receptor agonist. ${ }^{34}$ Although LPM is stable to dephosphorylation by LPP, ${ }^{34}$ LPM-induced scratching almost completely subsided within 20 minutes, and this temporal pattern was the same as that for LPA and histamine. To evaluate the characteristics of LPA-induced scratching, we examined antagonists that target specific LPA receptors. Significant inhibition (70\%; $P<0.05$ ) was demonstrated by the $\mathrm{LPA}_{1}$ and $\mathrm{LPA}_{3}$ receptor antagonist, Ki16425, but not DGPP (8:0), an $\mathrm{LPA}_{3}-$ selective antagonist. LPA-induced scratching was also significantly reduced by s.c. pretreatment with the opioid $\mu$ receptor antagonist, naloxone (Figure 6B).

\section{Discussion}

In the present study, we injected ICR mice intradermally with LPA or a related analogue, and confirmed the important finding that an intradermal injection of LPA increased 
scratching behaviors due to itching, consistent with previous reports. ${ }^{27,35}$ Our current work provides the novel finding that the LPA-induced itch-scratch response is due, at least in part, to an $\mathrm{LPA}_{1}$ receptor- and opioid-mediating mechanism. Intraplantar administration of LPA into the hind limb was reported to cause a pronociceptive effect through a release of substance $\mathrm{P}$ from peripheral nerve endings in mice. ${ }^{36}$ Although the mechanism of the peripheral opioidmediated itch is unclear, Bigliardi-Qi et $\mathrm{al}^{37}$ showed that $\mu$ opioid receptors are expressed in keratinocytes and unmyelinated peripheral nerve fibers in human dermis and epidermis. Furthermore, previous studies have shown that opioid $\mu$ antagonists inhibit the substance $\mathrm{P}$-induced itch in mice $^{25}$ and alleviate the itch in patients with AD and cholestatic pruritus. ${ }^{38}$ On the basis of these results, it is possible that LPA acts as a nerve-modulating substance on pruritus-specific nerves in the skin via opioidergic systems. Interestingly, pretreatment with naltorexon, a $\mu$ opioid receptor antagonist, was shown to suppress sphingosylphosphorylcholine-induced scratching in mice. ${ }^{39}$ Hashimoto et $\mathrm{al}^{27}$ showed that pretreatment with ketotifen, a histamine $\mathrm{H}_{1}$ receptor antagonist, and capsaicin inhibited LPA-induced itching in mice. Although we have no direct evidence for the involvement of endogenous histamine release in the LPA-induced scratching of ICR mice under our conditions, the nonadditive effects of intradermal injections of LPA and histamine for the scratching response suggest that involvement of the release of endogenous histamine is only partial, if present. Although the precise mechanism of LPA-induced scratching under chronic pruritic conditions in NOA mice is unclear, cross talks between LPA and neuromediators (histamine, substance $\mathrm{P}$, and nerve growth factor) may participate in augmentations of pruriception, sprouting of epidermal nerve fibers, and hypersensitivity, and may further augment the vicious cycle (Figure 7).

Our results support the hypothesis that an increased plasma concentration of LPA is one of the causative factors of pruritic dermatitis in NOA mice, which spontaneously develop systemic dermatitis. Consistent with this hypothesis, Kremer et $\mathrm{al}^{35}$ found that both the serum LPA level and LPA-producing activity were elevated in cholestatic pruritus patients with intense pruritus, especially in pregnant patients. Notably, our results showed that the pathological increase of plasma LPA in NOA mice is attributable to increased lysoPLD activity in the blood, rather than that of plasma, because of ATX. The same divalent cation is required for blood lysoPLD activity as for that of plasma, which suggests that the predominant portion of lysoPLD activity is attributable to blood cell-associated ATX. The

A
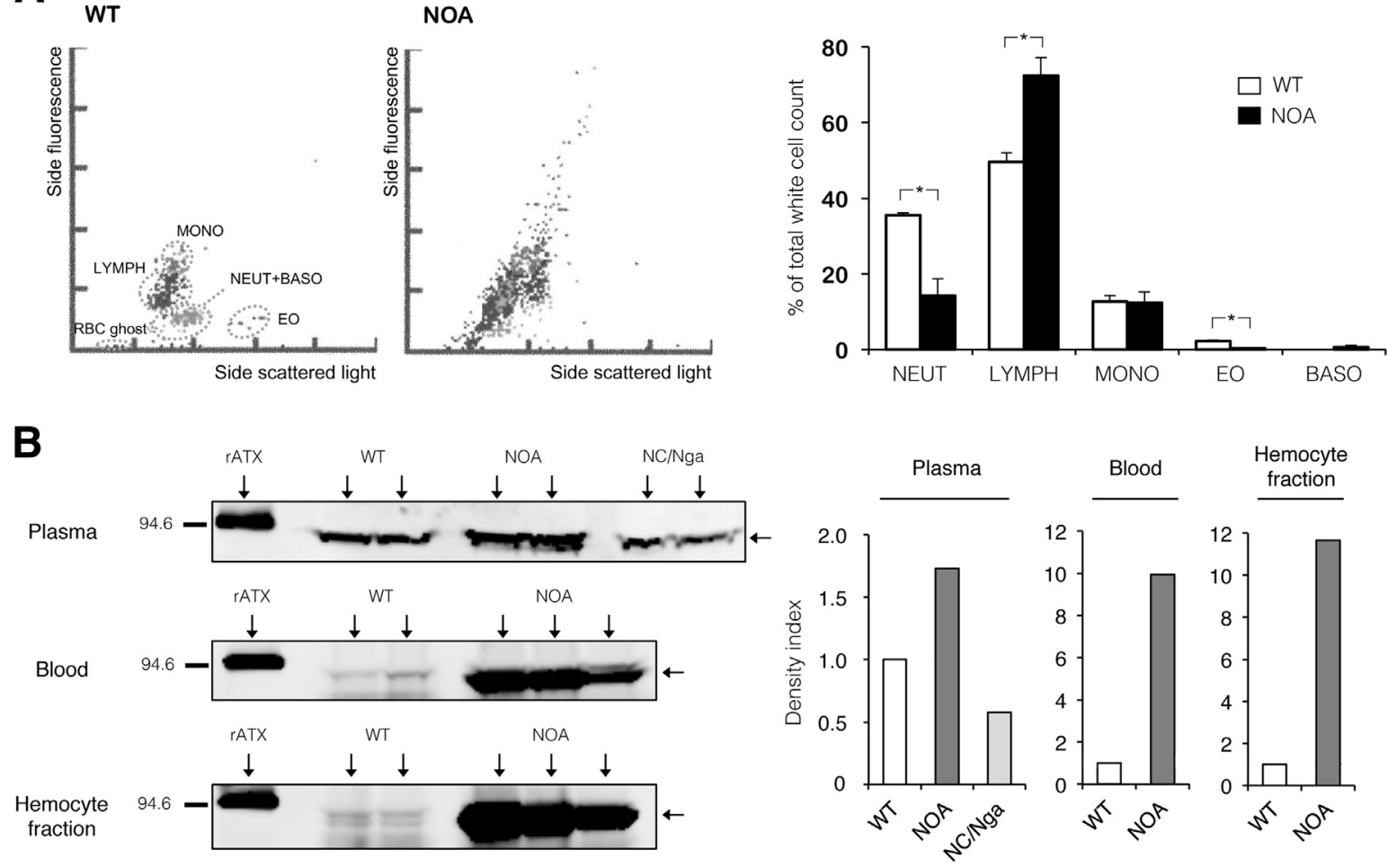

Figure 5 Lymphocytes are a potential target for binding with ATX in the density of NOA mouse circulation. A: Left panel: Representative WBC differential scattergrams of age-matched WT and NOA mice ( $>14$ weeks old). Right panel: subpopulations of WBCs from blood of age-matched WT and NOA mice ( $>14$ weeks old). Sysmex XT-2000iV (Sysmex Corp) was used for experiments. Data are means \pm SE of four mice per group. B: Western blot analysis of ATX protein in $0.003 \mathrm{~mL}$ each of plasma, blood, and hemocyte fraction of indicated strains was performed with anti-ATX antibody. Bar chart shows the mean of band intensity ratios between WT and NOA (or NC/Nga) mice. Values are relative to those of WT, set as 1 . The signal intensity of each band was quantified using the software Multi Gauge, version 3.2 (Fujifilm). Human recombinant ATX (rATX) was used as a positive control. ${ }^{\star} P<0.01$ versus WT. BASO, basophil; E0, eosinophil; LYMPH, lymphocyte; MONO, monocyte; NEUT, neutrophil. 
A

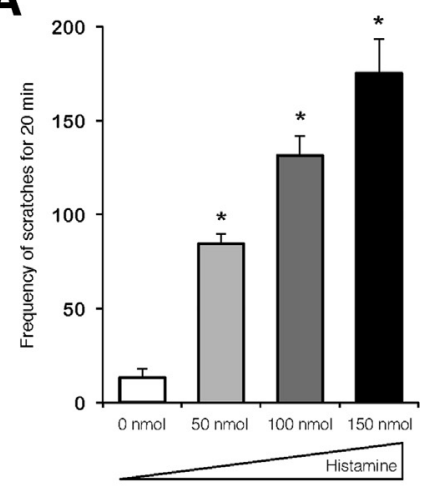

B

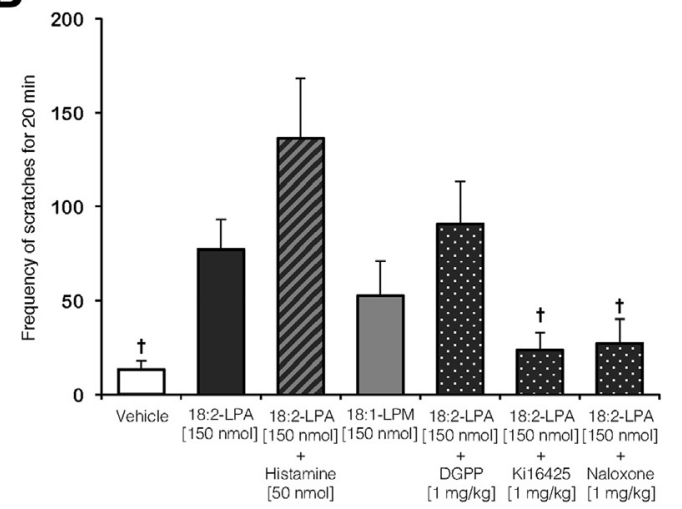

Figure 6 Itch-scratch responses after intradermal injection of histamine, LPA, and LPM. A pruritic agent was administered intradermally into the rostral region of the back. The number of itchscratch responses was observed and recorded for 20 minutes. A: Dose dependence of the scratching induced by 50,100 , and $150 \mathrm{nmol}$ per site histamine. B: Itch-scratch response induced by $150 \mathrm{nmol}$ per site 18:2-LPA, $150 \mathrm{nmol}$ per site 18:2-LPA plus $50 \mathrm{nmol}$ per site histamine, or $150 \mathrm{nmol}$ per site 18:1-LPM in the combination of $1 \mathrm{mg} / \mathrm{kg}$ DGPP, 1 $\mathrm{mg} / \mathrm{kg} \mathrm{Ki16425}$, or $1 \mathrm{mg} / \mathrm{kg}$ naloxone. Data are means \pm SE of three to six mice per group. ${ }^{*} P<0.05$ versus $0 \mathrm{nmol}$ per site histamine; ${ }^{\dagger} P<0.05$ versus $150 \mathrm{nmol}$ per site 18:2-LPA. efficient inhibition of blood lysoPLD activity by an ATX inhibitor also supports this suggestion. To our knowledge, this is the first measurement of the blood cell-associated lysoPLD activity of ATX. Interestingly, we observed a significant decrease in lysoPLD activity of blood when we treated the blood with heparinase III. This suggests that HSPGs mediate the binding of blood cells to ATX, and that blood cell-associated ATX has higher lysoPLD activity than soluble ATX. This may explain why lysoPLD activity of the blood is higher than that of the plasma in mice. Two recent reports on the crystal structure of ATX revealed a hydrophobic channel for the passage of LPA from the active site of ATX to the exit, allowing its subsequent transfer to LPA receptors embedded in the plasma membranes. ${ }^{40,41}$ Sequestration of ATX protein by HSPGs may accelerate the transport of LPA to the cell surface, including LPA receptors, thus promoting the rate of LPC decomposition by ATX in vivo.

Linkage analysis has demonstrated that the major genes responsible for dermatitis in the NOA and $\mathrm{NC} / \mathrm{Nga}$ mice are located on murine chromosomes 14 and 9 , respectively. ${ }^{42,43}$ NOA mouse also possesses two additional modifier genes on chromosomes 7 and $13 .{ }^{44}$ Although numerous studies are performed with animal models and human subjects, the atopy gene has not yet been identified. ${ }^{45}$ Herein, we observed increased circulating LPA level only in NOA, but not in $\mathrm{NC} / \mathrm{Nga}$, mouse. It is unclear, at present, how this difference between these mice is generated. However, with age, atopic lesions develop progressively and expand to cover a wide area of the animal's skin in NOA mice. Unlike the NOA mouse, NC/Nga mice commonly develop an atopic lesion around the face. Hence, the difference in circulating LPA level between NOA and NC/Nga mouse can be partly accounted for by considering the pathophysiological role of LPA as a systemic mediator. Furthermore, in contrast to NOA, NC/Nga mice only develop AD-like skin lesions when they are kept under conventional conditions. ${ }^{46}$ Thus, various environmental allergens undoubtedly affect the development of dermatitis in NC/Nga mice.

Constitutive expression of ATX in high endothelial venules (HEVs) is involved in homing of lymphocytes to secondary lymphoid organs from the blood vasculature through elevation of local concentrations of LPA. ${ }^{31,47}$ The secreted ATX from HEVs was supposed to bind with activated $\alpha 4 \beta 1$ integrins on human $\mathrm{T}$ lymphocytes. ${ }^{31}$ The transmigration of naïve $\mathrm{T}$ lymphocytes through the HEVs was found to be stimulated by local LPA production of ATX attached to the venules because HA130, an ATX inhibitor, slowed the integrin-arrested T-lymphocyte migration. ${ }^{48}$ It remains to be determined what cell types are

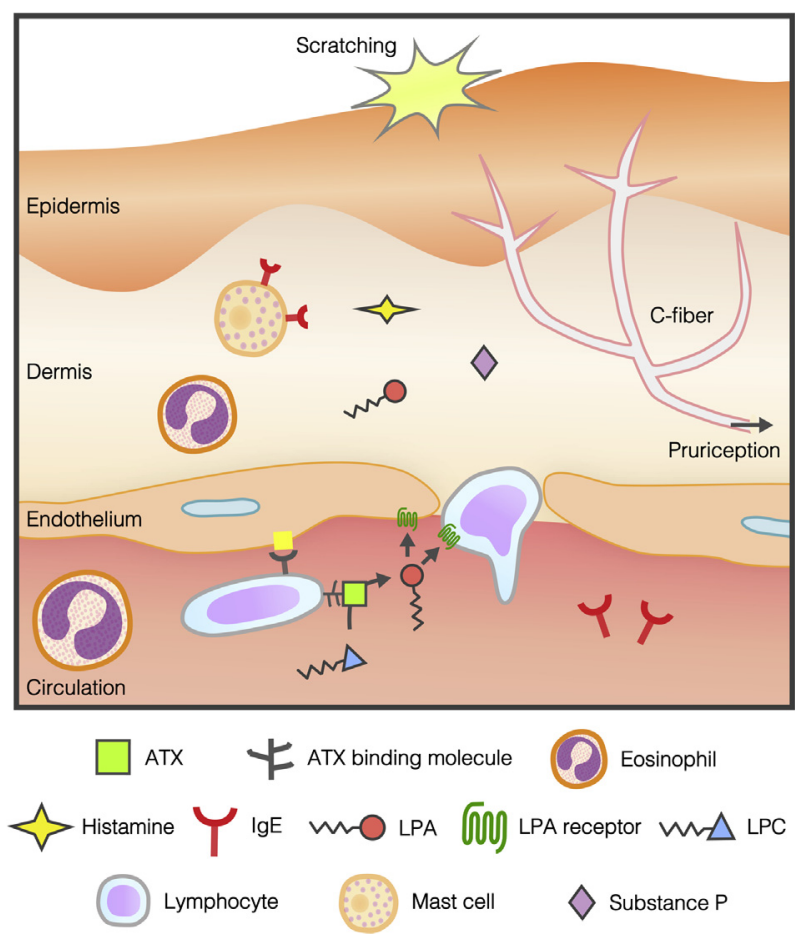

Figure 7 A hypothetical scheme of the role of local LPA-ATX coupling during pruriception in NOA mice. Blood cell-associated ATX elevates the local level of LPA in the blood vessel lumen, which may cause endothelial hyperpermeability and facilitate the migration of WBCs into dermal inflammatory areas. Subsequently, the resultant sinking of bloodborne LPA into the dermal tissues serves as a peripheral itch mediator. We speculate that residential and infiltrating immune cells release itch mediators (LPA, histamine, and substance $P$ ) toward receptors on c-fibers in dermal allergic inflammation of NOA mice. 
involved in the elevated ATX secretion in NOA mice. Chronically inflamed vessels can develop $\mathrm{ATX}^{+}$HEV-like vessels, ${ }^{47,49}$ which are potential sources of ATX in the NOA blood. We speculate that the production of LPA in the vicinity of the endothelium increased by activated leukocytes (leading to enhanced binding of ATX to leukocytes) and by differentiated vessels that are phenotypically and functionally similar to HEVs. In the spleens of NOA mice, mRNA expressions of platelet factor 4 (CXCL4), eotaxin [chemokine ligand (CCL) 11], and regulated on activation normal T-cell expressed and secreted (CCL5) are elevated compared with those in the control BALB/c mice, indicating a mechanism of localization of eosinophils to ulcerative skin lesions. ${ }^{50}$ Although the cell population associated with ATX remains uncharacterized in NOA mice, ATX/LPA may play a role in increased eosinophil trafficking into inflamed skin tissues.

Several lines of evidence suggest that residential cells, such as keratinocytes, mast cells, and infiltrating immune cells, including lymphocytes and eosinophils, play a role in the release of itch mediators toward receptors on c-fibers in dermal allergic inflammation. ${ }^{51}$ Although we do not know what signaling molecules are involved in the up-regulation of ATX expression in the circulation of NOA mice, elevated local LPA production in the blood lumen may cause the hyperpermeability of venules and facilitate the pathological uptake of immune cells to the lesional skin sites, aggravating the lesion progression. Indeed, LPA was shown to induce plasma exudation and up-regulated intercellular adhesion molecule-1 in human umbilical cord vein endothelial cells. ${ }^{16,52}$ Moreover, we speculate that immune cells, such as eosinophils and lymphocytes, in inflammatory skin areas release a variety of proinflammatory molecules, including lysophospholipids, as pathophysiological substrates of lysoPLD/ATX (originating from increased numbers of mast cells) to form LPA as an initiator of itching.

Elevated secretion of ATX in the blood circulation and/or an increased proportion of cell-associated ATX compared with soluble ATX may lead to more intensive local induction of allergic reaction because i.p. administration of schistosomal-derived LPC, a major physiological substrate of lysoPLD activity of ATX, was shown to participate in production of cytokines, including eotaxin/CCL11, and eosinophil recruitment into the peritoneal cavity in a mechanism of toll-like receptor 2-dependent mechanism in mice ${ }^{53}$ Further extensive studies are needed to understand the pathophysiological role of increased LPA production by cell-associated and secreted ATX in the local site of mouse skin.

\section{Acknowledgments}

We thank Dr. Taizo Kondo, Takeshi Kawano, and Tetsuya Fukunaga (Otsuka Pharmaceutical Factory) for their thoughtful advice on this study.

\section{References}

1. Boguniewicz M, Leung DY: Atopic dermatitis: a disease of altered skin barrier and immune dysregulation. Immunol Rev 2011, 242: $233-246$

2. Jin H, He R, Oyoshi M, Geha RS: Animal models of atopic dermatitis. J Invest Dermatol 2009, 129:31-40

3. Matsuda H, Watanabe N, Geba GP, Sperl J, Tsudzuki M, Hiroi J, Matsumoto M, Ushio H, Saito S, Askenase PW, Ra C: Development of atopic dermatitis-like skin lesion with $\operatorname{IgE}$ hyperproduction in NC/Nga mice. Int Immunol 1997, 9:461-466

4. Kondo T: The NOA mouse: a new hair-deficient mutant (a possible animal model of allergic dermatitis). Mouse Genome 1997, 95: $698-700$

5. Tokumura A: A family of phospholipid autacoids: occurrence, metabolism and bioactions. Prog Lipid Res 1995, 34:151-184

6. Choi JW, Herr DR, Noguchi K, Yung YC, Lee CW, Mutoh T, Lin ME, Teo ST, Park KE, Mosley AN, Chun J: LPA receptors: subtypes and biological actions. Annu Rev Pharmacol Toxicol 2010, 50:157-186

7. Zheng Y, Kong Y, Goetzl EJ: Lysophosphatidic acid receptorselective effects on Jurkat $\mathrm{T}$ cell migration through a Matrigel model basement membrane. J Immunol 2001, 166:2317-2322

8. Stam JC, Michiels F, Van der Kammen RA, Moolenaar WH, Collard JG: Invasion of T-lymphoma cells: cooperation between Rho family GTPases and lysophospholipid receptor signaling. EMBO J 1998, 17:4066-4074

9. Hashimoto T, Yamashita M, Ohata H, Momose K: Lysophosphatidic acid enhances in vivo infiltration and activation of guinea pig eosinophils and neutrophils via a Rho/Rho-associated protein kinasemediated pathway. J Pharmacol Sci 2003, 91:8-14

10. Zhao Y, Tong J, He D, Pendyala S, Evgeny B, Chun J, Sperling AI, Natarajan V: Role of lysophosphatidic acid receptor LPA2 in the development of allergic airway inflammation in a murine model of asthma. Respir Res 2009, 10:114

11. Idzko M, Laut M, Panther E, Sorichter S, Dürk T, Fluhr JW, Herouy Y, Mockenhaupt M, Myrtek D, Elsner P, Norgauer J: Lysophosphatidic acid induces chemotaxis, oxygen radical production, $\mathrm{CD} 11 \mathrm{~b}$ up-regulation, $\mathrm{Ca} 2+$ mobilization, and actin reorganization in human eosinophils via pertussis toxin-sensitive $\mathrm{G}$ proteins. J Immunol 2004, 172:4480-4485

12. Tokumura A: Metabolic pathways and physiological and pathological significances of lysolipid phosphate mediators. J Cell Biochem 2004, 92:869-881

13. Ren HM, Panchatcharam M, Mueller P, Escalante-Alcalde D, Morris AJ, Smyth SS: Lipid phosphate phosphatase (LPP3) and vascular development. Biochim Biophys Acta 2013, 1831:126-132

14. Tanaka M, Okudaira S, Kishi Y, Ohkawa R, Iseki S, Ota M, Nojim S, Yatomi Y, Aoki J, Arai H: Autotaxin stabilizes blood vessels and is required for embryonic vasculature by producing lysophosphatidic acid. J Biol Chem 2006, 281:25822-25830

15. Lundequist A, Boyce JA: LPA5 is abundantly expressed by human mast cells and important for lysophosphatidic acid induced MIP-1 $\beta$ release. PLoS One 2011, 6:e18192

16. Hashimoto T, Ohata H, Honda K: Lysophosphatidic acid (LPA) induces plasma exudation and histamine release in mice via LPA receptors. J Pharmacol Sci 2006, 100:82-87

17. Bagga S, Price KS, Lin DA, Friend DS, Austen KF, Boyce JA Lysophosphatidic acid accelerates the development of human mast cells. Blood 2004, 104:4080-4087

18. Tanaka T, Ikita K, Ashida T, Motoyama Y, Yamaguchi Y, Satouchi K: Effects of growth temperature on the fatty acid composition of the free-living nematode Caenorhabditis elegans. Lipids 1996, 31:1173-1178

19. Tokumura A, Iimori M, Nishioka Y, Kitahara M, Sakashita M, Tanaka S: Lysophosphatidic acids induce proliferation of cultured 
vascular smooth muscle cells from rat aorta. Am J Physiol 1994, 267: C204-C210

20. Kokusho Y, Kato S, Machida H, Iwasaki S: Purification and properties of phospholipase D from Actinomadura sp. strain No. 362. Agric Biol Chem 1987, 51:2515-2524

21. Kondo K: Differences in hematopoietic death among inbred strains of mice. Comparative Cellular and Species Radiosensitivity. Edited by VP Bond, T Sugahara. Tokyo, Igaku Shoin, 1969, pp $20-22$

22. Tokumura A, Carbone LD, Yoshioka Y, Morishige J, Kikuchi M, Postlethwaite A, Watsky MA: Elevated serum levels of arachidonoyllysophosphatidic acid and sphingosine 1-phosphate in systemic sclerosis. Int J Med Sci 2009, 6:168-176

23. Tokumura A, Majima E, Kariya Y, Tominaga K, Kogure K, Yasuda K, Fukuzawa K: Identification of human plasma lysophospholipase D, a lysophosphatidic acid-producing enzyme, as autotaxin, a multifunctional phosphodiesterase. J Biol Chem 2002, 277: 39436-39442

24. Tanaka M, Kishi Y, Takanezawa Y, Kakehi Y, Aoki J, Arai H: Prostatic acid phosphatase degrades lysophosphatidic acid in seminal plasma. FEBS Lett 2004, 571:197-204

25. Andoh T, Nagasawa T, Satoh M, Kuraishi Y: Substance P induction of itch-associated response mediated by cutaneous NK1 tachykinin receptors in mice. J Pharmacol Exp Ther 1998, 286:1140-1145

26. Inagaki $\mathrm{N}$, Nagao $\mathrm{M}$, Igeta $\mathrm{K}$, Kawasaki $\mathrm{H}$, Kim JF, Nagai $\mathrm{H}$ : Scratching behavior in various strains of mice. Skin Pharmacol Appl Skin Physiol 2001, 14:87-96

27. Hashimoto T, Ohata H, Momose K: Itch-scratch responses induced by lysophosphatidic acid in mice. Pharmacology 2004, 72:51-56

28. Yamamoto A, Sugimoto Y: Involvement of peripheral mu opioid receptors in scratching behavior in mice. Eur J Pharmacol 2010, 649: 336-341

29. Aoki J, Taira A, Takanezawa Y, Kishi Y, Hama K, Kishimoto T, Mizuno K, Saku K, Taguchi R, Arai H: Serum lysophosphatidic acid is produced through diverse phospholipase pathways. J Biol Chem 2002, 277:48737-48744

30. Fulkerson Z, Wu T, Sunkara M, Kooi CV, Morris AJ, Smyth SS: Binding of autotaxin to integrins localizes lysophosphatidic acid production to platelets and mammalian cells. J Biol Chem 2011, 286: 34654-34663

31. Kanda H, Newton R, Klein R, Morita Y, Gunn MD, Rosen SD: Autotaxin, an ectoenzyme that produces lysophosphatidic acid, promotes the entry of lymphocytes into secondary lymphoid organs. Nat Immunol 2008, 9:415-423

32. Houben AJ, van Wijk XM, van Meeteren LA, van Zeijl L, van de Westerlo EM, Hausmann J, Fish A, Perrakis A, van Kuppevelt TH, Moolenaar WH: The polybasic insertion in autotaxin $\alpha$ confers specific binding to heparin and cell surface heparan sulfate proteoglycans. J Biol Chem 2013, 288:510-519

33. Tokumura A, Miyake M, Yoshimoto O, Shimizu M, Fukuzawa K: Metal-ion stimulation and inhibition of lysophospholipase D which generates bioactive lysophosphatidic acid in rat plasma. Lipids 1998, 33:1009-1015

34. Endo T, Kano K, Motoki R, Hama K, Okudaira S, Ishida M, Ogiso H, Tanaka M, Matsuki N, Taguchi R, Kanai M, Shibasaki M, Arai H, Aoki J: Lysophosphatidylmethanol is a pan lysophosphatidic acid receptor agonist and is produced by autotaxin in blood. $\mathrm{J}$ Biochem 2009, 146:283-293

35. Kremer AE, Martens JJWW, Kulik W, Rueff F, Kuiper EMM, van Buuren HR, van Etpecum KJ, Kondrackiene J, Prieto J, Rust C, Geenes VL, Williamson C, Moolenaar WH, Beuers U, Oude Elferink RP: Lysophosphatidic acid is a potential mediator of cholestatic pruritus. Gastroenterology 2010, 139:1008-1018

36. Renbäck $\mathrm{K}$, Inoue $\mathrm{M}$, Ueda $\mathrm{H}$ : Lysophosphatidic acid-induced, pertussis toxin-sensitive nociception through a substance $\mathrm{P}$ release from peripheral nerve endings in mice. Neurosci Lett 1999, 270: $59-61$
37. Bigliardi-Qi M, Sumanovski LT, Büchner S, Rufli T, Bigliardi PL: $\mathrm{Mu}$-opiate receptor and Beta-endorphin expression in nerve endings and keratinocytes in human skin. Dermatology 2004, 209:183-189

38. Phan NQ, Bernhard JD, Luger TA, Ständer S: Antipruritic treatment with systemic $\mu$-opioid receptor antagonists: a review. J Am Acad Dermatol 2010, 63:680-688

39. Kim HJ, Kim H, Han ES, Park SM, Koh JY, Kim KM, Noh MS, Kim JJ, Lee CH: Characterizations of sphingosylphosphorylcholineinduced scratching responses in ICR mice using naltrexon, capsaicin, ketotifen and Y-27632. Eur J Pharmacol 2008, 583:92-96

40. Nishimasu H, Okudaira S, Hama K, Mihara E, Dohmae N, Inoue A, Ishitani R, Takagi J, Aoki J, Nureki O: Crystal structure of autotaxin and insight into GPCR activation by lipid mediators. Nat Struct Mol Biol 2011, 18:205-212

41. Hausmann J, Kamtekar S, Christodoulou E, Day JE, Wu T, Fulkerson Z, Albers HM, van Meeteren LA, Houben AJ, van Zeijl L, Jansen S, Andries M, Hall T, Pegg LE, Benson TE, Kasiem M, Harlos K, Kooi CW, Smyth SS, Ovaa H, Bollen M, Morris AJ, Moolenaar WH, Perrakis A: Structural basis of substrate discrimination and integrin binding by autotaxin. Nat Struct Mol Biol 2011, 18:198-204

42. Natori K, Tamari M, Watanabe O, Onouchi Y, Shiomoto Y, Kubo S, Nakamura Y: Mapping of a gene responsible for dermatitis in NOA (Naruto Research Institute Otsuka Atrichia) mice, an animal model of allergic dermatitis. J Hum Genet 1999, 44:372-376

43. Kohara Y, Tanabe K, Matsuoka K, Kanda N, Matsuda H, Karasuyama H, Yonekawa H: A major determinant quantitative-trait locus responsible for atopic dermatitis-like skin lesions in NC/Nga mice is located on Chromosome 9. Immunogenetics 2001, 53:15-21

44. Watanabe $\mathrm{O}$, Tamari M, Natori $\mathrm{K}$, Onouchi $\mathrm{Y}$, Shiomoto $\mathrm{Y}$, Hiraoka I, Nakamura Y: Loci on murine chromosomes 7 and 13 that modify the phenotype of the NOA mouse, an animal model of atopic dermatitis. J Hum Genet 2001, 46:221-224

45. Morar N, Willis-Owen SA, Moffatt MF, Cookson WO: The genetics of atopic dermatitis. J Allergy Clin Immunol 2006, 118:24-34

46. Suto H, Matsuda H, Mitsuishi K, Hira K, Uchida T, Unno T, Ogawa H, Ra C: NC/Nga mice: a mouse model for atopic dermatitis. Int Arch Allergy Immunol 1999, 120(Suppl 1):70-75

47. Nakasaki T, Tanaka T, Okudaira S, Hirosawa M, Umemoto E, Otani K, Jin S, Bai Z, Hayasaka H, Fukui Y, Aozasa K, Fujita N, Tsuruo T, Ozono K, Aoki J, Miyasaka M: Involvement of the lysophosphatidic acid-generating enzyme autotaxin in lymphocyteendothelial cell interactions. Am J Pathol 2008, 173:1566-1576

48. Zhang Y, Chen YCM, Krummel MF, Rosen SD: Autotaxin through lysophosphatidic acid stimulates polarization, motility, and transendothelial migration of naive T cells. J Immunol 2012, 189:3914-3924

49. Hozumi H, Hokari R, Kurihara C, Narimatsu K, Sato H, Sato S, Ueda T, Higashiyama M, Okada Y, Watanabe C, Komoto S, Tomita K, Kawaguchi A, Nagao S, Miura S: Involvement of autotaxin/lysophospholipase D expression in intestinal vessels in aggravation of intestinal damage through lymphocyte migration. Lab Invest 2013, 93:508-519

50. Watanabe O, Natori K, Tamari M, Shiomoto $\mathrm{Y}$, Kubo S, Nakamura Y: Significantly elevated expression of PF4 (platelet factor 4) and eotaxin in the NOA mouse, a model for atopic dermatitis. J Hum Genet 1999, 44:173-176

51. Ständer S, Raap U, Weisshaar E, Schmelz M, Mettang T, Handwerker H, Luger TA: Pathogenesis of pruritus. J Dtsch Dermatol Ges 2011, 9:456-463

52. Lee H, Lin CI, Liao JJ, Lee YW, Yang HY, Lee CY, Hsu HY, Wu HL: Lysophospholipids increase ICAM-1 expression in HUVEC through a Gi-and NF-אB-dependent mechanism. Am J Physiol 2004, 287:C1657-C1666

53. Magalhães KG, Almeida PE, Atella GC, Maya-Monteiro CM, CastroFaria-Neto HC, Pelajo-Machado M, Lenzi HL, Bozza MT, Bozza PT: Schistosomal-derived lysophosphatidylcholine are involved in eosinophil activation and recruitment through Toll-like receptor-2dependent mechanisms. J Infect Dis 2010, 202:1369-1379 